\title{
PIPING PLOVER RESEARCH AND CONSERVATION IN CANADA
}

PAUL GOOSSEN, Canadian Wildlife Service, Room 210, 4999 - 98 Avenue, Imonton, Alberta. T6B 2X3

The Piping Plover is a small North nerican shorebird which received relaely little attention from researchers til the 1980s when concern was exessed that this species had suffered a ious population decline. ${ }^{31}$ In 1985, the mmittee on the Status of Endangered Idlife in Canada (COSEWIC) declared Piping Plover to be an endangered cies based on a status report recomindation, ${ }^{31}$ while the United States Fish Wildlife Service (USFWS) declared plover to be endangered in the Great es region and threatened elsewhere as 1986.7 In 1988, the population on the rth American breeding grounds was mated to be about 4300 adults (Table Piping Plovers winter in the southern ited States, Mexico and on Caribbean nds, ${ }^{36}$ however wintering ground surs have only accounted for about 1730 individuals (adults and young in their first year). ${ }^{65}$

About the turn of the last century, hunting contributed to the plover's decline? but more recently, water level regulation, habitat modification, predation and human disturbance have been implicated. ${ }^{41}$

The present overview, an expanded version of an upcoming article, ${ }^{30}$ provides an update on surveys, research and conservation activities by various Canadian agencies and provides a major focus on the period 1985-1988. Information prior to this period can be found in Haig ${ }^{31}$ and McNicholl ${ }^{61}$ while some material, falling in the period discussed in this current paper, has been discussed by McNicholl ${ }^{61}$ and Haig and Oring. ${ }^{37}$

le 1. NORTH AMERICAN PIPING PLOVER POPULATION ESTIMATES FOR 1988.

\author{
Number of \\ adults \\ 925 \\ 1612 \\ Source \\ see Table 2 \\ Susan Haig, unpubl. data
}

Susan Haig, unpubl. data

Susan Haig, unpubl. data

see Table 2

Anonymous ${ }^{5}$ 


\section{Surveys - Distribution and Abun- dance}

\section{National Perspective}

The Piping Plover is found in nine of the ten Canadian provinces ${ }^{36}$ (Figure 1) and breeds in two principal regions defined in this paper as Prairie Canada (Alberta, Saskatchewan, Manitoba, western Ontario) and Atlantic Canada (Quebec, Nova Scotia, New Brunswick, Prince Edward Island, Newfoundland). Until 1977, Piping Plovers also nested in the Canadian Great Lakes region ${ }^{55}$ although breeding may have occurred more recently, in 1981 and $1988 .{ }^{\circ}$
Based on 1988 data, about $32 \%$ (nea 1400 adults) of the North Americ Piping Plover population ocicurs Canada (Table 1 and 2). Estimates of Canadian population, published in $19 i$ ranged from about 715-1115 pairs; ${ }^{36} 71$ estimate for 1986 was about 800-8 pairs ${ }^{47}$ and less than 700 pairs for 19 (Table 2). An international Piping Plo súrvey in 1991 on both breeding a wintering grounds will provide the $b$ population estimates to date.

\section{Prairie Canada}

Sixty-six percent of the Canadi population is found in Prairie Cana

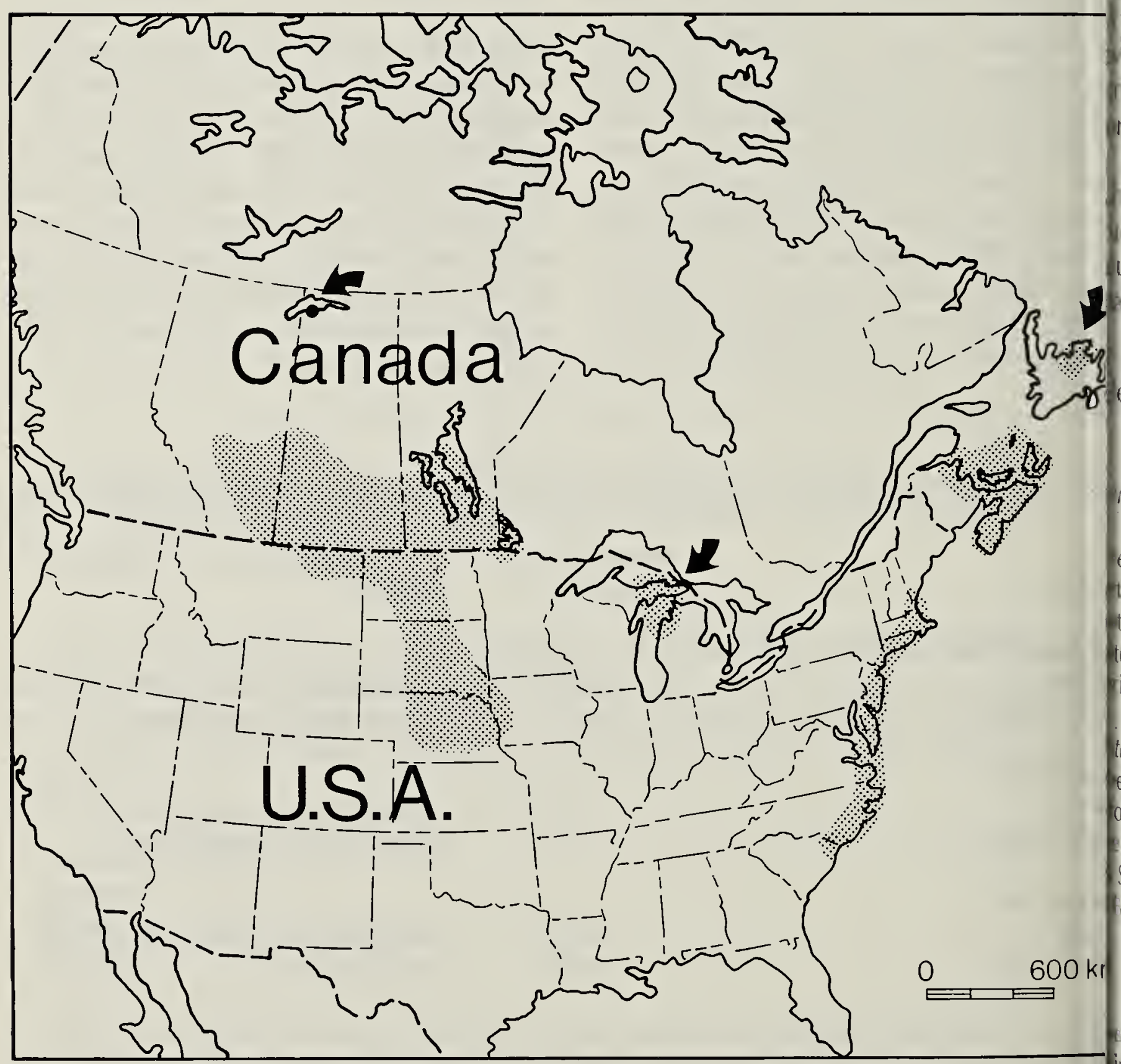

Figure 1. North American breeding distribution of the Piping Plover (after Haig al. ${ }^{41}$ and S. Haig, pers. comm.) 
ble 2). In Alberta, the Piping Plover eding population prior to 1978 was mated to be $100-110$ pairs, ${ }^{84}$ but the major survey, carried out in 1986 , aled a total of 288 adults. ${ }^{83}$ Additional s checked in 1987 resulted in one e breeding area being located near tiskow. ${ }^{79}$ Since 1900, habitat loss in erta is thought to have resulted in a ease in breeders of less than 10\%, ever drought conditions in 1988 Ited in no productivity at some loca$s$ and is thought to have influenced a ine in the provincial population. ${ }^{82}$

e northern-most Canadian record of ding Piping Plovers occurred in Sashewan at Lake Athabasca and exed the previously known range by km.' Recent occurrences of Piping ers in Saskatchewan have mostly documented on lands under federal ovincial jurisdiction. ${ }^{17}$

anging habitat conditions, ${ }^{43}$ possible ction in the population ${ }^{32}$ and data Iation $^{73}$ have influenced the intertion of Saskatchewan Piping Plover population estimates. In 1984, the Saskatchewan population was estimated to be between 2000-2500 plovers. This estimate was based on known and extrapolated data from lake surveys plus an estimate of the remaining potential habitat for plovers in Saskatchewan. ${ }^{48}$ However, the 1986 provincial estimate was down $67 \%$ at about $700-800$ adults $^{41}$ and down further to 500 individuals in 1988 (Wayne Harris, pers. comm.). Big Quill Lake, one of the largest and most populated breeding sites in North America, was estimated to have $300+$ adults in $1985^{47}$ but a survey done the following year reported less than $50 \%$ of that number. ${ }^{42}$ The adult population count was up somewhat in 1987, but the number of observed young was down by $46 \%$ from $1986 .{ }^{44}{ }^{42}$ Ir. 1988, only 107 adults and 17 young were reported. Drought conditions $^{45}$ probably contributed to decreased numbers of plovers at Big Quill Lake with adults possibly going to different sites. ${ }^{42}$

Populations at Redberry Lake, a site considered for recreational develop-

\section{CANADIAN PIPING PLOVER POPULATION ESTIMATES FOR $1988 .{ }^{\mathrm{a}}$}

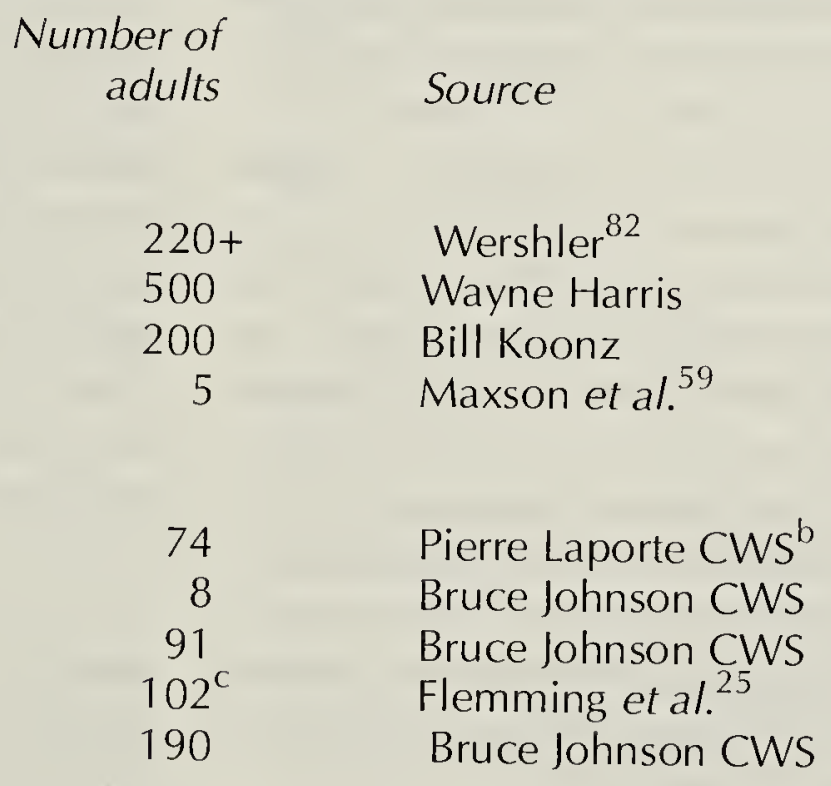

1390

estimates reflect 1987 or earlier data as complete surveys were not carried out in all nces in 1988.

- Canadian Wildlife Service.

rge taken of 1987 range (48-54 pairs). 
ment, ${ }^{74}$ remained stable at or about 40 individuals in $1984^{48}$ and $1985 .^{53}$ At Lake Diefenbaker, an artificial lake created by damming the South Saskatchewan River, fluctuating water levels significantly influence habitat availability for Piping Plovers. In 1984, when water levels were low and habitat was available to plovers, 223 individuals were seen during a survey of about $63 \%$ of the eastern part of Lake Diefenbaker's shoreline. ${ }^{48}$ In 1986, plovers did not nest because of high water levels. ${ }^{46}$ Habitat was available in 1988, however, only 97 adults were found even though more shoreline was covered $^{46}$ than in $1984 .^{48}$

Relatively few plovers have been reported on river habitat in Prairie Canada. This contrasts with considerable use of riverine sandbar habitat by plovers in the American great plains. ${ }^{41}$ The discovery, in 1988, of 44 plovers along the South Saskatchewan River downstream from Lake Diefenbaker ${ }^{66}$ has increased an awareness of the plover's use of river habitat in Prairie Canada. It is not known what, if any, importance rivers have as an alternative nesting area for displaced breeding plovers during drought years when lakes such as Chaplin and Old Wives have little or no water and very few plovers (Wayne Harris, unpubl. data).

Manitoba's plover population, based on data from surveys carried out prior to 1987, is estimated to be about 120-130 individuals. $^{33}{ }^{34}$ Several previously unknown sites with one or more plovers were located in 1987 by the Manitoba Department of Natural Resources. ${ }^{64}$ In 1988 the population was estimated at close to 200 plovers. This increase is thought to have possibly been a result of drought in other areas influencing plovers to move into Manitoba. ${ }^{54}$

The Piping Plovers at Lake of the Woods in western Ontario are included in the plains population. ${ }^{69}$ This is the only known annual breeding population in
Ontario $^{55}$ consisting of up to $10 \mathrm{ad}$ (1981-1988). 5550515259

\section{Great Lakes Canada}

Historically, the Great Lakes popu tion in Ontario has been estimated about 150-160 pairs, with most at $L_{c}$ Erie, particularly Long Point. ${ }^{69} \mathrm{~T}$ species' decline in the Great Lakes regi has been so great that it can be $\mathrm{cr}$ sidered extirpated ${ }^{69}$ although there two possible breeding records (1981 1988) in the last decade. ${ }^{9}$ Human dist bance $^{69}$ and predation ${ }^{55}$ are thought have contributed to the decline. ${ }^{69}$

\section{Atlantic Canada}

The Piping Plover population in Atl: tic Canada ranged from about 445-5 adults based on 1982 and 1984 inform tion. $^{36}$ The 1988 population estimate Atlantic Canada, 465 adults, is proximately $34 \%$ of the Canadian plo population with $82 \%$ of the Atlan Canada plovers occurring in $\mathrm{N}$ Brunswick, Nova Scotia and Prince ward Island (Table 2). In these la provinces, the annual breeding popt tion at three National Parks has rang from 45 to 52 pairs during 1984 to 19 The lowest breeding population Kouchibouguac National Park, N Brunswick, was recorded in $1988 \mathrm{n}$ only nine breeding pairs reported, do from the high of 21 in 1983. In contr; Prince Edward Island National Park $\mathrm{H}$ its highest count in 1988, with 28 bre ing pairs located. ${ }^{13}$ The breeding pope tion in Kejimkujik National Park's Seas Adjunct, Nova Scotia has varied fror high of at least 27-29 pairs in 1976 (d only from Cadden Beach ${ }^{10}$ currently Catherines River Beach ${ }^{68}$ ), to nine bre ing pairs in $1987 .{ }^{13}$ In 1988, the Canad Parks Service (CPS), in addition to surv ing plovers in National Parks, also s veyed nine provincial beaches in $\mathrm{Nc}$ Scotia and recorded $12-14$ breeding $p$ and 13 fledged chicks. ${ }^{67}$ In Quebec population is estimated to be less than pairs (Table 2). Since 1979, populat 
timates for the Magdalen Islands have ried from 30 pairs in $1979^{12}$ to 20 pairs $1983^{18}$ to 37 pairs plus four individuals 1987. ${ }^{70}$ Surveys prior to 1987 were not onsidered to be exhaustive as was the 187 survey, and therefore evaluating the ppulation trend is difficult. ${ }^{70}$ However e latter report concluded the population as fairly stable. In the 1980s, the Newundland plover population appears to ve remained at less than 12 adults (Joe azil, pers. comm.).

n Nova Scotia, a decrease of 3.3-5.8 irs/year was believed to have occurred m 1983 to $1987 . .^{25}$ In Quebec, adults d young were seen along the Gulf of St. wrence's north shore as recently as $86,{ }^{87}$ however no Piping Plovers were n during a 1988 survey. ${ }^{20}$

\section{search}

tional Perspective

inly four major research projects on ing Plover biology have been comted in Canada - two in Prairie Canada ${ }^{35}$ id two in Atlantic Canada. ${ }^{1023}$

\section{- irie Canada}

Whyte conducted a two-year study at Quill Lake, a large prairie lake in katchewan. His fieldwork conrated on breeding chronology, teriality, choice of nest locations and oductive success. Hatching success only $28.6 \%$ in 1980 and $8.8 \%$ in 1 while fledging success was considly higher $(66.7 \%$ in 1980 and $86.0 \%$ 981). Predation by Ring-billed Gulls suspected and may have caused the nest success. ${ }^{85}$

Manitoba, Haig carried out a major of the breeding biology of Piping ers. ${ }^{35}$ She found that almost $70 \%$ of ts which survived returned the foling year to the area where they had and that there was no significant ence in return rates between males females. Although most pairs changed mates between years, the majority retained mates after nest loss. ${ }^{39}$ Like Whyte, ${ }^{85}$ Haig found nest success to be poor with $64 \%$ of the nests failing in her study, most likely because of predation, storms and human disturbance. She determined that only about one chick fledged from a nest. ${ }^{39}$ Haig also did genetic research on various North American populations; no convincing support could be found for taxonomically dividing this plover into two subspecies ${ }^{38}$ as does the American Ornithologists' Union. ${ }^{2}$ Haig has also provided the most comprehensive overview of Piping Plover distribution in North and Latin America. ${ }^{36} 40$

A recent analysis of Piping Plover productivity data from the Prairie Canada and American great plains population questions whether the population will sustain itself since not enough young may be being produced. Using a theoretical model to determine productivity required for population stability, researchers determined that between 1.15-1.44 fledged chicks/pair is required to maintain the western population. Known productivity was found to be only $1.12 \pm 0.33$ (standard error) fledged chicks/pair in the prairie and plains population. Theoretical production values, which serve as a tentative benchmark need to be tested further. $^{27}$

\section{Atlantic Canada}

Cairn's research in Nova Scotia resulted in the first comprehensive description of Piping Plover territorial and courtship behaviour. ${ }^{10}$ "She found that fledging success was lower on beaches with greater recreational activity compared with her main study area, Cadden Beach, which had more limited recreational use..$^{12} \mathrm{~A}$ one-season study by Tull in and near Kouchibouguac National Park, New Brunswick, found that reproductive success in early nests was greater than those initiated later. ${ }^{76}$ Tull also found that human disturbance or lack thereof, was 
not an important factor affecting productivity, however disturbance was relatively limited at his study site and may not have been sufficient to show an impact. Further study in Nova Scotia revealed that disturbance was not an important factor for young chicks (10 days) but was for older chicks (17 days). ${ }^{25}$ For this latter group, significantly fewer survived per pair (0.5) on beaches with disturbance compared with those surviving (1.8) on beaches with less activity. This study suggests behavioural changes in response to human presence such as decreased chick brooding and feeding, may make chicks more vulnerable to predation and the elements.

Productivity has also been determined by CPS for Piping Plovers breeding in some Atlantic National Parks. The number of chicks fledged per pair has varied from 1.5-2.2 in Kouchibouguac National Park ${ }^{76}{ }^{13}$ to $0.7-2.8$ in Prince Edward Island National Park ${ }^{15}{ }^{63}{ }^{86}$ to $0.3-2.1$ in Kejimkujik National Park. ${ }^{68} 11$

In Nova Scotia, during 1979-1983, fledging success was reported to be 1.2 chicks/pair/nest initiated. ${ }^{25}$ It should be noted that there is variation in the above studies as to the definition of a fledged chick and some give minimum-maximum ranges because of the difficulty in determining the number of fledged chicks.

\section{Conservation}

\section{National Perspective}

Piping Plovers are protected by the Migratory Birds Convention Act of 1917 and additional conservation measures are afforded through the Canada Wildlife Act of 1973. As of fall 1990, Canada has no federal endangered species act, but Manitoba (Bill Koonz, pers. comm.), Quebec (Pierre Laporte, pers. comm.), Ontario and New Brunswick have endangered species legislation." At the national level, species status designations in
Canada are assigned by COSEWIC but not carry legislative powers.

After the Piping Plover's status $h$ been upgraded in 1985 from threater to endangered in Canada by COSEW steps were taken to develop a natio approach to conserving the species laying the groundwork for a natio recovery plan. ${ }^{60}$ The recovery plan $^{6}$ been approved (Tim Lash, pers. com and is complementary to the $t$ American recovery plans already place. ${ }^{22}{ }^{41}$ Research and conservation tions, outlined in the Canadian Pip Plover Recovery Plan, are aimed at reta ing the Canadian plover population a its distribution. Overall Canadi recovery efforts are administered thro a national coordinator while two regio teams are responsible for regional $\mathrm{pl}$ ning. Recently, Canada and the Uni States have recognized that internatio cooperation is important to Piping Plo conservation and have participated jo ly in recovery team meetings.

Federal, provincial and nongove ment agencies have initiated a variet research and/or conservation measi (Table 3). Nongovernment agencies $h$ been successful in providing publi about the plover's plight and have s ported plover surveys and conservati For example, the Canadian Nat Federation has been active in hab preservation (B. T. Aniskowicz, p comm.) and through its publication, ture Canada, has made Canadians an of this plover. ${ }^{322}{ }^{74}$ Support for survey $\mathrm{n}$ has come from World Wildlife F (WWF), the Elsa Wild Animal Appea Canada, the Saskatchewan Natural tory Society (SNHS), ${ }^{29}$ the Province Quebec Society for the Protection Birds $^{70}$ and the Natural History Societ Prince Edward Island (NHSPEI) (Dan Askill, pers. comm.). Ducks Unlimi SNHS, Wildlife Habitat Canada WWF have supported habitat enhar ment efforts (Dale Hjertaas, pers. com 


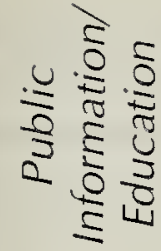

$\frac{\pi}{d}$
$\sum^{2}$
$\frac{0}{2} \frac{\pi}{2}$
$\frac{\pi}{2}$

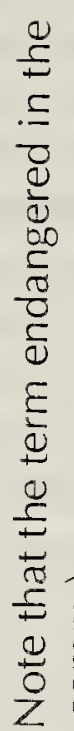
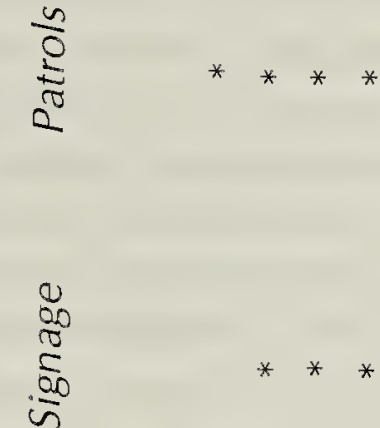

$\frac{\pi}{0}$
$\frac{\pi}{0} \frac{5}{0}$
$\frac{\pi}{0}$
$\frac{0}{0}$

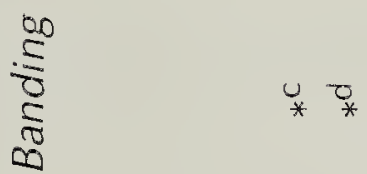

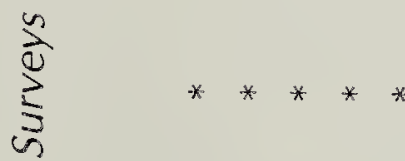

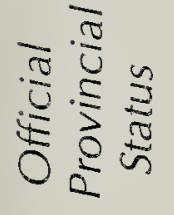
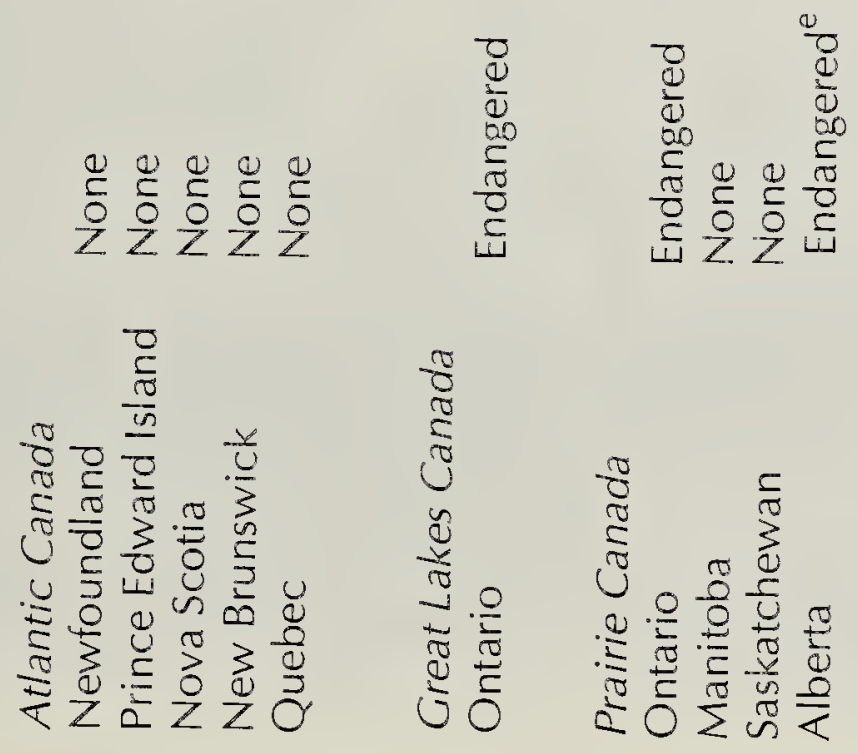

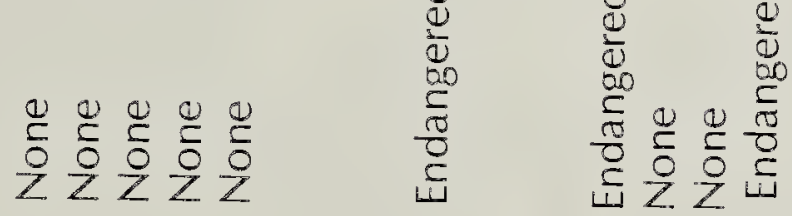

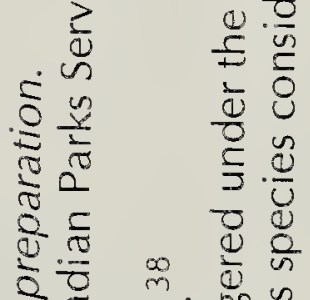

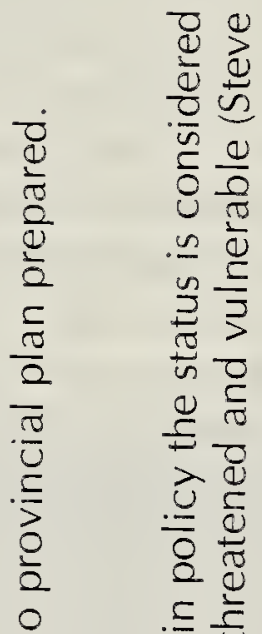

Z. \pm

它 قठ

ล $\quad \overline{0}$

है

变

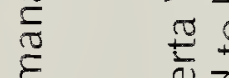

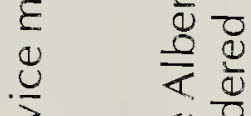

ฮิ

$\frac{5}{\frac{3}{7}}$

$\frac{8}{\infty}$ 


\section{Prairie Canada}

Within the last five years, the participation of agencies in Piping Plover conservation in Prairie Canada has increased and demonstrates a heightened interest in this migratory plover. The Prairie Piping Plover Recovery Team has identified priority action plans. ${ }^{29}$ These strategies will serve to implement the interests of the national plan at the regional level. In addition to the national recovery plan, provincial management or recovery plans have been initiated in Ontario, ${ }^{28}$ Manitoba $^{348}$ and Alberta. ${ }^{82}$

General suggestions regarding Piping Plover management in Alberta have been previously outlined ${ }^{78}$ while specific management suggestions have been made for protecting plover habitat from cattle disturbance and/or recreational activities at Little Fish Lake and one of the Reflex Lakes. ${ }^{80}{ }^{81}$ Habitat enhancement projects have been initiated in both Saskatchewan and Manitoba. Nesting substrate has been increased at two lakes in Saskatchewan, Chaplin ${ }^{45 a}$ and Little Quill, through the spreading of gravel on lakeshore habitat (Dale Hjertaas, pers. comm.). Since Piping Plovers successfully use a variety of artificial habitats for nesting, ${ }^{41}$ a proposed dyke to enhance waterfowl production, at Old Wives Lake in southern Saskatchewan, if constructed, may provide suitable plover nesting habitat. $^{32}$ In Manitoba, habitat modification has been attempted at Lake Winnipeg (Bill Koonz, pers. comm.) and Lake Manitoba. ${ }^{34}$ In 1982, breeding habitat on the southeastern shore of Lake Manitoba was protected by the Manitoba government declaring the site a Special Conservation Area. $^{34} \mathrm{~A}$ sign at Sable Islands Provincial Nature Reserve, Lake of the Woods, Ontario was erected in part to contribute to conserving breeding Piping Plovers (Leo Heyens, pers comm.).

\section{Great Lakes Canada}

Although Piping Plovers do not currently breed in this part of Canada, both the proposed national ${ }^{6}$ and Ontari recovery plans have set as one of the goals, the re-establishment, if feasible, the plover in this region.

\section{Atlantic Canada}

Of nine National Parks and one Natio at Park Reserve in Atlantic Canada, on Prince Edward Island National Par Kouchibouguac National Park ar Kejimkujik National Park's Seaside A junct harbour Piping Plovers. Each these three parks has a management pl. for Piping Plovers. ${ }^{14}{ }^{26}{ }^{68}$ CPS has us signs, fences and warden patrols to affo protection to some nesting areas and $i$ terpretive hikes, slide shows ar pamphlets assist in educating the gener public (Gary Corbett, pers. comm.). Sin maritime storms cause nest loss ${ }^{4} \mathrm{CPS} h$ considered removing eggs, incubati them and then replacing them (Gary Co bett, pers. comm.). Piping Plover eg have been successsfully hatched by arti cial means and the resulting you released into the wild. ${ }^{63}$ Predation is co sidered to be a greater problem th human disturbance in Atlantic Canac but it may be related indirectly to hum activity (Gary Corbett, pers. comm.). forts to control predators have been tempted $^{67}$ and nest exclosures have be successfully used in decreasing prec tion. ${ }^{21}$ Since there is evidence to sugg that plovers have a higher hatching st cess when nesting near breeding ter than in the terns' absence, considerati should be given to the suggestion manage tern colonies in order to bent plover conservation. ${ }^{16} \mathrm{CPS}$ has also $\mathrm{co}$ piled an extensive bibliography with or 200 references cited on literature perta ing to this species. ${ }^{57}$

For more than 10 years, the NHSPEI been actively promoting Piping Plor conservation. The society has conduct surveys for plovers, helped in planni workshops, initiated a program to cont landowners, and supported public re tion efforts including a Piping Plo 
account of the Piping Plover populations within their jurisdictions. Furthermore, population estimates in Saskatchewan have varied considerably between researchers, and the importance of clarifying the abundance of plovers in this province is of international significance, as the estimated population may account for $12 \%$ (Table 1 ) to perhaps $50 \%$ of the total continental population. ${ }^{48}$

In Prairie Canada there are several concerns which need to be addressed. Further clarification of the plover's distribution and protection of its habitat is needed. As to research, long-term data are needed on population dynamics, dispersal and productivity to determine the nature of population fluctuations and the adequacy of reproductive output in maintaining a self-sustaining population.

In Atlantic Canada, information is needed on wintering locations of the breeding population (Richard Dyer, pers. comm.) while research and management is required to reduce nesting failure caused by predators and storms. The possible impact of illegal shorebird hunting in some locations in Newfoundland ${ }^{19}$ should be evaluated and appropriate action taken to provide public education. In both Atlantic and Prairie regions, conservation must take priority if the plover's status is to be downlisted or de-listed. In order to effectively conserve the continental breeding population of Piping Plovers, joint action by Americans and Canadians $^{72}$ must continue in cooperation with those Latin American countries where the plovers winter. Finally, it is of utmost importance that landowners and the general public take responsible conservation actions for habitat preservation during occupational and recreational activities.

\section{Acknowledgements}

I thank B. T. Aniskowicz (Canadian Nature Federation), Peter Austin-Smith (Nova Scotia Department of Lands and Forests), Irene Bowman (Ontario Ministry of Natural Resources (OMNR)), Joe Br (Department of Culture, Recreation Youth, Newfoundland), Joe Carre (Canadian Wildlife Service (CWS), tario), David Cartwright (Department Natural Resources, New Brunswic Gary Corbett (CPS, Atlantic Region), Darby (OMNR), Randy Dibblee (Dep ment of Community and Cultural Affa Prince Edward Island), Richard D (USFWS), Gary Erickson (Departmen Forestry, Lands and Wildlife (DFLW), berta), Dale Hjertaas (Department Parks and Renewable Resources (DPF Saskatchewan), Bruce Johnson (CWS, lantic Region), Bill Koonz (Departmen Natural Resources, Manitoba), Pir Laporte (CWS, Quebec Region), Mic Lepage (Ministère du Loisir de la Cha et de la Pêche, Quebec) Dan McAs (NHSPEI) and Dave Moore (DFLW, Alb ta) for providing me with information research and/or conservation in th various jurisdictions. The Potash poration of Saskatchewan kin provided me with survey reports for Quill Lake. Gary Corbett (CPS), Ro Edwards (CWS), Gary Erickson (DFL Susan Haig (USFWS), Peter Hick (CWS), Dale Hjertaas (DPRR), Br Johnson (CWS), Pierre Laporte (CW Guy Morrison (CWS), Sheila Lamont (S katchewan Natural History Society) two reviewers each commented o draft(s) of the manuscript. Susan M Eachran (CWS) drafted the figure.

ADAM, C.I.G. 1984. Piping Plo Charadrius melodus, at Lake Athabas Saskatchewan: a significant northw range extension. Can. Field-Nat. 98:59

2 AMERICAN ORNITHOLOGIS UNION. 1983. Check-list of No American birds, 6 th ed. Am. Ornith. Uni Washington, D.C. 877 pp.

3 ANONYMOUS. 1986. Plover targe conservationists. Nat. Canada 15(1):4气

4 ANONYMOUS. 1986. Annual rev 1985-1986. Can. Wildl. Serv. 35 pp. 
ANONYMOUS. 1989. Birdnotes. The iving Bird 8(3):5.

ATLANTIC AND PRAIRIE PIPING LOVER RECOVERY TEAMS. In preparaon. Canadian Piping Plover recovery plan.

BENT, A.C. 1929. Life histories of orth American shore birds. Smiths. Inst. S. Nat. Mus. Bull. 146.

BERGER, R. 1988. Piping Plover Charadrius melodus) recovery plan for anitoba. Unpubl. draft. Univ. of Man. 45 . plus appendices.

BURNETT, J. A., C. T. DAUPHINÉ, Jr., S. MCCRINDLE and T. MOSQUIN. 889. On the brink. Western Producer airie Books, Saskatoon. 192 pp.

AIRNS, W.E. 1977. Breeding biology id behaviour of the Piping Plover haradrius melodus) in southern Nova cotia. Unpubl. M. Sc. thesis, Dalhousie hiv. 100 pp. plus appendices.

AIRNS, W.E. 1982. Biology and bevior of breeding Piping Plovers. Wilson ill. 94:531-545.

AIRNS, W.E. and I.A. MCLAREN. 80. Status of the Piping Plover on the st coast of North America. Am. Birds :206-208.

ORBETT, G.N. 1988. Summary port. Status of Piping Plover in Canada's tional Parks 1988. Unpubl. Can. Parks rv. report. 4 pp.

DRBETT, G.N. and B.I. BALL. 1980. management plan for Piping Plover, aradrius melodus, in Prince Edward Isd National Park. Unpubl. report for ks Canada, Atlantic Region. 61 pp. plus endices.

OWE, A. 1984. Piping Plover surPrince Edward Island National Park. ubl. report for the Can. Wildl. Serv. and ks Canada. 23 pp. plus tables, figures appendices.

OWE, A. 1987. 1987 Piping Plover vey Prince Edward Island National k. Unpubl. Parks Canada draft report.
17 DALE, B. 1986. Land tenure of areas critical to Piping Plovers in Saskatchewan. Unpubl. report prepared for the Sask. Natural History Soc., Saskatoon. 24 pp.

18 DAVID, N. 1983. The nesting season June 1 - July 31, 1983. Quebec Region. Am. Birds 37:970-971.

${ }^{19}$ DEICHMANN, $\mathrm{H}$. and R. BURROWS. 1983. Importance of the northeast coast of Newfoundland from Deadmans Bay to Cape Freels to migrant and nesting shorebirds and the threat these birds face from illegal shooting. Osprey 14:9-14.

${ }^{20}$ DEMERS, A. and P. LAPORTE. 1988. Inventaire des habitats du Pluvier siffleur sur la Côte Nord et en Gaspésie. Unpubl. Can. Wildl. Serv. report. 45 pp.

${ }^{21}$ DRYSDALE, C., D. REIVE and G. KENNEY 1988. An evaluation of Piping Plover (Charadrius melodus) nest protection strategy in the Kejimkujik National Park Seaside Adjunct. Unpubl. Can. Parks Serv. report. $11 \mathrm{pp}$.

22 DYER, R.W., A. HECHT, S. MELVIN, C. RAITHEL and K. TERWILLIGER. 1988. Atlantic Coast Piping Plover recovery plan. U. S. Fish and Wildl. Serv., Newton Corner, Mass. 66 pp. plus an appendix.

${ }^{23}$ FLEMMING, S.P. 1984. The status and responses of Piping Plover (Charadrius melodus Ord) to recreational activity in Nova Scotia. Unpubl. B. Sc. thesis, Acadia Univ. 46 pp. plus tables, figures and appendices.

${ }^{24}$ FLEMMING, S.P. 1987. Natural and experimental adoption of Piping Plover chicks. J. Field Ornithol. 58:270-273.

${ }^{25}$ FLEMMING, S.P., R.D. CHIASSON, P.C. SMITH, P.J. AUSTIN-SMITH and R.P. BANCROFT. 1988. Piping Plover status in Nova Scotia related to its reproductive and behavioral responses to human disturbance. J. Field Ornithol. 59:321-330.

${ }^{26}$ FONTAINE, N. and G. DELANEY. 1985. Piping Plover management plan 
Kouchibouguac National Park. Unpubl. report for Parks Canada, Atlantic Region. 18 pp. plus appendices.

27 GAINES, E.P. and M.R. RYAN. 1988. Piping Plover habitat use and reproductive success in North Dakota. J. Wildl. Mgmt. 52:266-273.

${ }^{28}$ GERSON, H. 1988. Recovery plan for the Piping Plover in Ontario. Unpubl. draft. Ont. Ministry of Natural Resources.

${ }^{29}$ GOOSSEN, J.P. 1989. Prairie Piping Plover conservation: first annual report (1988). Unpubl. Can. Wildl. Serv. report. 19 pp.

30 GOOSEN, J.P.(sic) 1990. Surveys and conservation of Piping Plovers in Canada. Wader Study Group Bull. 57:53-57.

${ }^{31}$ HAIG, S. 1985. The status of the Piping Plover in Canada. Report to the Committee on the Status of Endangered Wildlife in Canada. Nat. Mus. of Natural Sciences, Ottawa. 34 pp.

32 HAIG, S. 1986. Ducks Unlimited Wood River Delta/Old Wives Lake development: Piping Plover assessment. Unpubl. report to Ducks Unlimited Canada. 11 pp. plus appendix and attachments.

${ }^{33}$ HAIG, S. 1986. Distribution and status of Piping Plovers in Manitoba - 1986. Unpubl. report prepared for the Man. Dept. of Natural Resources and World Wildlife Fund (Canada). 10 pp.

${ }^{34}$ HAIG, S.M. 1987. Piping Plovers in Manitoba - a status report on the species and initial recovery plan for the province. Pp. 243-247 In HOLROYD, G.L., W.B. MCGILLIVRAY, P.H.R. STEPNEY, D.M. EALEY, G.C. TROTTIER, and K.E. EBERHART. Proceedings of the workshop on endangered species in the prairie provinces. Prov. Mus. of Alberta Occ. Paper No. 9. $367 \mathrm{pp}$.

35 HAIG, S.M. 1987. The population biology and life history patterns of the Piping Plover. Ph.D. dissertation, Univ. of $\mathrm{N}$. Dakota. $121 \mathrm{pp}$.
36 HAIG, S.M. and L.W. ORING. 198 Distribution and status of the Piping Plov throughout the annual cycle. J. Field C nithol. 56:334-345.

37 HAIG, S.M. and L.W. ORING. 198 The Piping Plover. Pp.508-519 In Audub Wildl. Report 1987. Nat. Audubon Sc Academic Press, Orlando.

38 HAIG, S.M. and L.W. ORING. 198 Genetic differentiation of Piping Plove across North America. Auk 105:260-267

39 HAIG, S.M. and L.W. ORING. 198 Mate, site, and territory fidelity in Pipil Plovers. Auk 105:268-277.

40 HAIG, S.M. and L.W. ORING. 198 Distribution and dispersal in the Pipi Plover. Auk 105:630-638.

41 HAIG, S., W. HARRISON, R. LOCK, PFANNMULLER, E. PIKE, M. RYAN and SIDLE. 1988. Great Lakes and Nort ern Great Plains Piping Plover recove plan. U. S. Fish and Wildl. Serv., TW Cities, Minn. 132 pp. plus appendices.

${ }^{42}$ HARRIS, W.C. 1986. Big Quill La Piping Plover population census - 198 Unpubl. report prepared for the Pota Corp. of Sask. 13 pp.

43 HARRIS, W.C. 1987. Saskatchewi Piping Plovers. Pp. 239-242 In HOLROY G.L., W.B. MCGILLIVRAY, P.H.R. STE NEY, D.M. EALEY, G.C. TROTTIER, at K.E. EBERHART. Proceedings of $t \mathrm{t}$ workshop on endangered species in $t$ prairie provinces. Prov. Mus. of Alber Occ. Paper No. 9. 367 pp.

44 HARRIS, W.C. 1987. Big Quill Lal Piping Plover population census - 198 Unpubl. report prepared for the Pota: Corp. of Sask. 11 pp.

45 HARRIS, W.C. 1988. Saskatchew: Piping Plover populations (1984 - 1988 Unpubl. abstract prepared for the Northe Great Plains Great Lakes Piping Plov meeting held in Lincoln, Neb., 1 Novemb 1988. 
HARRIS, W.C. 1988. Piping Plover census and evaluation of the effects of experimental habitat enhancement at Chaplin Lake, Saskatchewan. Unpubl. report prepared for Sask. Natural History Soc. 7 pp.

HARRIS, W.C. 1988. South Saskatchewan River Piping Plover Survey 1988 (Lake Diefenbaker segment - Riverhurst Ferry to Dam). Unpubl. report prepared for the Sask. Nat. History Soc. 10 pp. plus map.

HARRIS, W.C. and S.M. LAMONT. 1985. Big Quill Lake Piping Plover population survey -- 1985. Unpubl. report prepared for the Potash Corp. of Sask. 24 pp.

HARRIS, W., G. WAPPLE, R. WAPPLE, K. DESMET (sic) and S. LAMONT. 1985. Saskatchewan Piping Plovers - 1984. Unpubl. report prepared for the Sask. Nat. History Soc. and Sask. Parks and Renewable Resources Wildl. Branch. 106 pp. plus appendix.

HENGEVELD, H.G. 1987. Understanding $\mathrm{CO}_{2}$ and climate. Annual report 1986. Atmospheric Environment Serv., Environment Canada. $23 \mathrm{pp}$.

HEYENS, L.E. 1986. Piping Plover survey Sable Islands Provincial Nature Reserve. Unpubl. field report, Ont. Ministry of Natural Resources. 2 pp. plus map.

HEYENS, L.E. 1987. Piping Plover urvey Sable Islands Provincial Nature Reserve. Piping Plover survey Windy Point Lake of the Woods. Unpubl. field report, nnt. Ministry of Natural Resources. 3 pp. lus two maps.

HEYENS, L.E. 1988. Piping Plover urvey Sable Islands Provincial Nature ieserve. Piping Plover survey Windy Point ake of the Woods. Unpubl. field report, nnt. Ministry of Natural Resources. 2 pp. lus map and bird checklist.

KERBES, R.H. and J.L. HOWARD. 986. Summary of bird studies and lanagement recommendations for the edberry Lake area. Unpubl. report prepared by Can. Wildl. Serv. and Sask. Parks and Renewable Resources Wildl. Branch. 14 pp.

${ }^{54}$ KOONZ, W. 1988. Piping Plover observations Manitoba 1988. Unpublished Man. Dept. of Natural Resources report. 4 pp. plus a map.

55 LAMBERT, A.B. 1987. Piping Plover. Page 162 In Cadman, M.D., P.F.J. Eagles, and F.M. Helleiner. Atlas of the breeding birds of Ontario. Univ. of Waterloo Press, Waterloo. $617 \mathrm{pp}$.

${ }^{56}$ LAPORTE, P. 1988. Plan d'action pour le retablissement du Pluvier siffleur au Quebec. Unpubl. Can. Wildl. Serv. draft. 51 pp.

57 LEWIS, H. 1988. Piping Plover bibliography. Unpubl. draft. Can. Parks Serv., Atlantic Region. 23 pp.

${ }^{56}$ MACEACHERN, P. and S. BARRETT. 1988. A: Crowbush/Lakeside Piping Plover population survey and landowner contact program. B: Hillsborough Bridge piers Common Tern colony study. Natural History Soc. of Prince Edward Island 1988 Seeds project report. 20 pp. plus appendices.

59 MAXSON, S.J., K.V. HAWS and L.W. ORING. 1988. 1988 status and breeding summary of Piping Plovers and Common Terns at Lake of the Woods, Minnesota. Unpubl. Minn. Dept. of Natural Resources report. 8 pp. plus tables, banding schedule and a figure.

60 MCKEATING, G. 1987. A national perspective and management strategy on the Piping Plover. Pp. 233-234 In HOLROYD, G.L., W.B. MCGILLIVRAY, P.H.R. STEPNEY, D.M. EALEY, G.C. TROTTIER, and K.E. EBERHART. Proceedings of the workshop on endangered species in the prairie provinces. Prov. Mus. of Alberta Occ. Paper No. 9. 367 pp.

61 MCNICHOLL, M.K. 1985. Profiles on risk status of Canadian birds: 2. Piping Plover. Alta. Nat. 15:135-138. 
62 MCSWEENY, B.T. 1985. CNF launches plover action plan. Nat. Canada 14(4):53.

${ }_{63}$ MORSE. M. 1982. 1982 Piping Plover survey. Prince Edward Island National Park. Unpubl. Can. Wildl. Serv. and Parks Canada report. 25 pp. plus appendices.

${ }^{64}$ MOSZYNSKI, R., W.H. KOONZ and K. DE SMET. 1988. Manitoba Piping Plover survey, 1987. Unpubl. Man. Natural Resources Wildl. Biological Serv. manuscript report No. 88-03. 24 pp. plus appendices.

${ }^{65}$ NICHOLLS, J. 1988. Winter distribution of the Piping Plover (Charadrius melodus) along the Atlantic and Gulf Coasts. Unpubl. abstract prepared for the Northern Great Plains Great Lakes Piping Plover meeting held in Lincoln, Neb., 1 November 1988.

${ }^{66}$ PURDY, M.A. and B.J. WEICHEL. 1988. Piping Plover survey: South Saskatchewan River - Red Deer confluence to Miry Bay and Gardiner Dam to Saskatoon. Unpubl. report prepared for the Sask. Natural History Soc. 13 pp. plus appendices.

${ }^{67}$ REIVE, D. and G. KENNEY. 1988. Piping Plover (Charadrius melodus) monitoring program. Kejimkujik National Park Seaside Adjunct 1988. Unpubl. Can. Parks Serv. report. 35 pp. plus appendices.

${ }^{68}$ REIVE, D., G. KENNEY and C. DRYSDALE. 1988. A management plan for Piping Plover (Charadrius melodus) Kejimikujik National Park, Seaside Adjunct. Unpubl. Can. Parks Serv. report.

${ }^{69}$ RUSSELL, R.P. 1983. The Piping Plover in the Great Lakes region. Am. Birds 37:951-955.

70 SHAFFER, F. and C. PINEAU. 1987. État du pluvier siffleur (Charadrius melodus) aux îles-de-la-Madeleine. Assoc. québécoise des groupes d'ornithologues. $15 \mathrm{pp}$. plus map, graphs, tables and appendices. (English translation and French version accessed).
7 SIDLE, J.G. 1985. Endangered threatened wildlife and plants; determi tion of endangered and threatened sta for the Piping Plover. Fed. Regis 50(238):50726-50734.

72 SIDLE, J. 1987. Piping Plover on American great plains. Pp. 249 In $\mathrm{HC}$ ROYD, G.L., W.B. MCGILLIVRAY, P.H STEPNEY, D.M. EALEY, G.C. TROTTIE and K.E. EBERHART. Proceedings of workshop on endangered species in prairie provinces. Prov. Mus. of Albe Occ. Paper No. 9. 367 pp.

73 SMITH, A.R. 1986. An analysis Piping Plover surveys in Saskatchen with recommendations on survey pro dures. Unpubl. Can. Wildl. Serv. draft.

74 SPEER, C. 1987. Resort on plovert ritory. Nat. Canada 16(1):49.

75 TEMPLE, S.A. (ed.). 1978. dangered birds. Management techniqu for preserving threatened specis Proceedings of the symposium management techniques for preserv endangered birds. Univ. of Wisc. Pré Madison. 466 pp.

${ }^{76}$ TULL, C.E. 1984. Astudy of the nest Piping Plovers of Kouchibouguac Natio Park 1983. Unpubl. report prepared Parks Canada. 79 pp. plus appendices

77 VERSTEEG, H. 1984. The protect of endangered species: a Canad perspective. Ecology Law Quart. 11:2 304.

78 WERSHLER, C.R. 1987. The Pip Plover in Alberta. Pp. 235-237 In HC ROYD, G.L., W.B. MCGILLIVRAY, P.H STEPNEY, D.M. EALEY, G.C. TROTTIE and K.E. EBERHART. Proceedings of workshop on endangered species in prairie provinces. Prov. Mus. of Albe Occ. Paper No. 9. 367 pp.

79 WERSHLER, C.R. 1988. Piping Plo breeding habitat census and monitor program Alberta 1987. Unpubl. rep prepared for World Wildlife Fund Cana 
